\title{
A BRIEF REVIEW ON PHYTOCHEMICAL AND PHARMACOLOGICAL PROFILE OF CARISSA SPINARUM L.
}

\author{
IMTIYAZ ANSARI*, DIPTESH T PATIL
}

Department of Pharmacology, Oriental College of Pharmacy, Navi, Mumbai- 400 705, India. Email: imtiyaz.ansari@ocp.edu.in

Received: 28 March 2018, Revised and Accepted: 14 May 2018

\section{ABSTRACT}

Carissa spinarum L. belongs the Apocynaceae family, which officially itself has 94 synonyms and misspelled, misapplied, invalid, and illegitimate names. The plant is known as "Magic Shrub" in some of the African countries, as it is a source of treatment for various diseases and disorders. The plant contains certain major bioactive constituents such as acids, glycosides, terpenoids, alkaloids, tannins, and saponins which are responsible for medicinal value. Traditionally, the plant is used for treatment of malaria, chest complaints, stomach-ache, diarrhea, worms, a cough remedy, eye cataracts, gastric ulcers, polio, cancer, hypertension, kidney complication and for treating herpes, infertility, diabetes, asthma, rheumatism, and infections such as gonorrhea, syphilis, sickle-cell anemia, hernia, rabies, typhoid fever, jaundice, sexual asthenia in males, measles, and as a cough expectorant. Apart from this, the plant is evaluated for various pharmacological activities by employing the animal models. The review has been written with the aim to provide a direction for further clinical research to promote safe and effective herbal treatments to cure a number of diseases.

Keywords: Carissa spinarum L., Pharmacological activities, Medicinal properties, Traditional uses, Carissa edulis.

(C) 2018 The Authors. Published by Innovare Academic Sciences Pvt Ltd. This is an open access article under the CC BY license (http://creativecommons. org/licenses/by/4. 0/) DOI: http://dx.doi.org/10.22159/ajpcr.2018.v11i9.26316

\section{INTRODUCTION}

Carissa spinarum L., belongs to the dogbane family Apocynaceae [1], found to be widely distributed throughout tropical regions of Africa, Southern Asia, Australia, and various islands of the Indian Ocean. The shrub is commonly known as wild Karonda in India, referring to the related karanda (Carissa carandas). It is often misidentified as $C$. carandas due to similar appearance. Species in this family are significant in the food industry as well as in pharmacologically as traditional medicine. It is known as native currant or even blackcurrant in Australia; however, it is not related to Prunus or Currant species. In Africa, it is called as "enkeldoring-noemnoem" which means "simple-spine num-num" [2].

Carissa belongs to Apocynaceae family which contains 5 subspecies, 410 genera, and 5556 species. The Apocynaceae family has been known as one of the enormous flowering plant families. Carissa genus was listed more than 500 species, but most of them are relegated as synonyms. C. spinarum L. officially itself has 94 synonyms [3] and 7 misspelled, misapplied, invalid, and illegitimate names [4]. Some of these are shown in (Table 1).

As it is often misidentified as $C$. carandas, here is the difference between them [5]

C. carandas $C$. spinarum

\begin{tabular}{|c|c|}
\hline $\begin{array}{l}\text { 1. Lateral veins of leaf } 8 \\
\text { pairs }\end{array}$ & 1. Lateral veins of leaf $3-5$ pairs \\
\hline 2. Leaves $3.5-8 \mathrm{~cm}$ long & 2. Leaves $2-5 \mathrm{~cm}$ long \\
\hline $\begin{array}{l}\text { 3. Leaf apex rounded, } \\
\text { emarginated }\end{array}$ & $\begin{array}{l}\text { 3. Leaf apex acute or acuminate to } \\
\text { apiculate }\end{array}$ \\
\hline $\begin{array}{l}\text { 4. Fruit ellipsoid, } 15-25 \mathrm{~mm} \\
\text { long }\end{array}$ & 4. Fruit subglobose, $5-12 \mathrm{~mm}$ \\
\hline 5. Ripe fruit reddish-purple & 5. Ripe fruit shining black \\
\hline 6. Corolla tube $2-2.5 \mathrm{~cm}$ long & 6. Corolla tube $1-1.5 \mathrm{~cm}$ long \\
\hline
\end{tabular}

1. Plant profile [6]

- Family: Apocynaceae

- Common names: Currant Bush, Conkerberry, Bush Plum, Burrum
Bush, Wild Karaunda.

2. Taxonomical hierarchy

- Kingdom: Plantae

- Subkingdom: Viridaeplantae

- Phylum: Tracheophyta

- Class: Magnoliopsida

- Subclass: Asteridae

- Order: Gentianales

- Family: Apocynaceae

- Genus: Carissa

- Species: Spinarum.

3. Vernacular names [7]

- Maharashtra: Karavada, Karanda, Karwant:

- Andhra Pradesh: Vaka, Kalivi, Kalli;

- Bengal: Karamacha;

- Gujarat: Karmarda;

- Karnataka: Karekayi, Garji, Kavali.

- Himachal Pradesh: Karondhu, Garna, Kharnu;

- Hindi: Karunda;

- Sanskrit: Karamarda, Avighna

- Tamil Nadu: Kalakkay, Kalachedi.

\section{MORPHOLOGY [9]}

1. Plant: Thorny shrub, with forked branches,

2. Height: $2-3 \mathrm{~m}$

3. Wood: Very hard;

4. Bark: Light brown to green,

5. Thorns: $3.2 \mathrm{~cm}$ long, at the base brown to greenish and toward the tip deep brown colored,

6. Leaves: Ovate, $4.5 \mathrm{~cm}$ long, $2.5 \mathrm{~cm}$ broad, leathery; venation, reticulate pinnate; margin, entire; petiole $3 \mathrm{~mm}$ long; leaves exuding a white latex, when plucked from the stem,

7. Flowers: Short-stalked, sweetly scented, bisexual, complete, and white colored,

8. Fruit: An ovoid berry, 5-12 $\mathrm{mm}$ in length, $6 \mathrm{~mm}$ in diameter, green when unripe, and Shining black when completely ripe (Fig. 1). 


\section{PHYTOCHEMICAL TESTING OF VARIOUS PARTS OF PLANT}

Leaves [10]

Phytochemical testing of leaves of C. spinarum L. are shown in (Table 3). And Phytochemical parameters of leaves of C. spinarum L. are shown in (Table 4).

\section{Roots and root bark}

Phytochemical testing of roots and root bark of C. spinarum L. are shown in (Table 5).

\section{Fruit [15]}

Phytochemical testing of fruit of C. spinarum L. are shown in (Table 6).

\section{Stem and stem bark [16]}

Phytochemical testing of stem and stem bark of C. spinarum L. are shown in (Table 7).

\section{CHEMICAL COMPOSITION [17-21]}

\section{Fruit}

It consists of acids, sugars, reducing sugars, non-reducing sugars, tannins, pectin and Vitamin C. Carissol (an epimer of A-amyrin), lupeol, oxalic, tartaric, citric, malic, malonic and glycolic acids, glycine, alanine, phenyl alkaline, cerine, glucose, and galactose.

\section{Root}

The chemical compositions in root are carissone, carindone, carinol, odoroside $\mathrm{H}$, digitoxigenin, glucose, and D- digitalose.

\section{Seed}

It consists of palmitic acid, stearic acid, oleic acid, arachidic acid, and linoleic acid.

Leave

It consists of triterpene alcohol and ursolic acid.

\section{Flower}

It consists of myrcene, limonene, camphene, canene, dipentene, farnesol, nerolidol, dihydrojasmone, A-terpeneol, citronellal, $\beta$-ionone, nerylacetate, linalool, and geranyl acetate.

\section{TRADITIONAL USE}

C. spinarum $\mathrm{L}$. is a one of the main African ethnomedicine; it is one of the most prevalent traditional cures for a myriad of diseases. All the plant parts, roots, barks, leaves, and even the fruits are used to treat many diseases. As a multipurpose medicinal tree, some communities across Africa refer to C. spinarum as the "magic herb" [22] because it is used
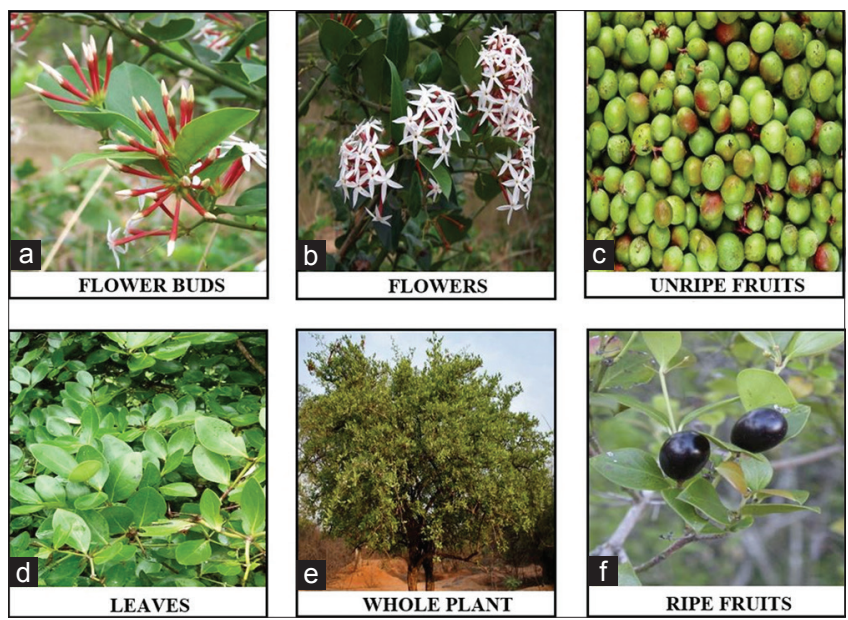

Fig. 1: Morphology of Carissa spinarum L., (a) flower buds (b) flowers (c) unripe fruits (d) leaves, (e) whole plant (f) ripe fruits to cure several diseases including headache, chest complaints [23], rheumatism [23-25], gonorrhea, syphilis, rabies, herpes, malaria [26], sickle-cell anemia, hernia, edema, toothache, cough, ulcer, worm infestation [27] and as a diuretic, also for the treatment of typhoid fever, jaundice [28], sexual asthenias in males, measles, and as a cough expectorant [29]. The plant is also useful in the treatment of chickenpox and other skin diseases [30]. The decoction from the pounded root is also administered to treat epilepsy in some communities. In some cases, the patient is made to inhale the vapors coming from the root infusion to treat epilepsy. The traditional birth attendants use the decoction from dried leaves to increase labor and bring about quick child delivery especially during difficult labor.

Like the roots, a decoction from the leaves and bark of $C$. spinarum is used in many societies in Africa in the treatment and management of breast cancer, headache, chest pains, gonorrhea, lowering blood pressure, rheumatism, syphilis, rabies, immune booster, fever, edema, cough, ulcer, malaria [31], and to relieve toothache. Roots and root bark are used as anti-venom and snake repellent [32,33]. The ripe fruits are eaten as snacks to treat and manage dysentery.

Apart from the plant being used as one of the most valued traditional medicinal plants and fruit trees, it has also found many other applications in a number of communities. For instance, C. spinarum can be an ornamental plant due to its abundant branching habit and the presence of thorns that make it suitable as a protective hedge plant, while its fruits are gathered and eaten as food and for the processing of traditional natural dyes.

\section{ETHNOPHARMACOLOGICAL SIGNIFICANCE}

C. spinarum is known to possess an extensive range of phytochemicals in its leaves, roots, barks, as well as fruits that impart enormous medicinal value to the plant. These active constituents offer medicinal value to the plant. Pharmacological importance of the plant fruits has been evaluated by several researchers through in vitro and in vivo advances. These activities of $C$. spinarum have been reported from the crude extract and their different fractions and isolates from fruit, leave, and root.

\section{PHARMACOLOGICAL ACTIVITIES}

\section{Anthelmintic activity}

Anthelmintic activity was evaluated on adult Indian earthworm Pheretima posthuma by Harwansh et al. 2010. Earthworm was selected because of its anatomical and physiological resemblance with the intestinal roundworm parasites of human beings. The study was done at three different concentrations, each of crude extract of methanolic, aqueous, and chloroform $(25,50$, and $100 \mathrm{mg} / \mathrm{ml}$ in distilled water) and Piperazine citrate served as standard drug. This study revealed that the methanolic $(100 \mathrm{mg} / \mathrm{ml})$ and chloroform extract (50 and $100 \mathrm{mg} / \mathrm{ml}$ ) have equivalent potency compared to PC $(10 \mathrm{mg} / \mathrm{ml})$ in the time taken for both paralysis and death of $P$. posthuma. The possible mechanism was concluded as increased chloride ion conductance of worm muscle membrane produces hyperpolarization and reduced excitability that leads to muscle relaxation and flaccid paralysis [34].

\section{Antiarthritic activity}

Hegde et al. 2010 evaluated antiarthritic activity of ethanolic extract of C. spinarum root in freund's adjuvant-induced polyarthritis in rats. Arthritis was induced by injecting $0.1 \mathrm{ml}$ of Freund's adjuvant in sub-plantar region. Treatments were given as $100 \mathrm{mg} / \mathrm{kg}$ of phenylbutazone as a standard and 100,200 , and $400 \mathrm{mg} / \mathrm{kg}$ doses of ethanolic extract of $C$. spinarum root. The study concluded that the plant extract doses had significant $(\mathrm{p}<0.05)$ dose-dependent antiarthritic activity [35].

\section{Anticonvulsant activity}

Ya'u et al. 2008 demonstrated significant anticonvulsant activity of hydroala coholic extract of root bark of $C$. spinarum in pentylenetetrazole 
(PTZ)-induced convulsion in mice as well as maximal electroshockinduced convulsion in chicks. For anticonvulsant screening 5, 10, and $20 \mathrm{mg} / \mathrm{kg}$ of hydroalcoholic extract was given through IP route. Naloxone

Table 1: List of some synonyms of $C$. spinarum L. [4]

\begin{tabular}{ll}
\hline Carissa abyssinica R.Br. & Carissa inermis Vahl \\
Carissa Africana A.DC. & Carissa lanceolate R.Br. \\
Carissa axillaris Roxb. & Carissa laxiflora Benth. \\
Carissa brownie F. Muell. & Carissa macrophylla Wall. \\
Carissa campenonii (Drake) & Carissa madagascariensis \\
Palacky & Thouars ex Poir. \\
Carissa candolleana Jaub. and & Carissa obovate Markgr. \\
Spach & Carissa oleoides Markgr. \\
C. carandas var. & Carissa ovata R.Br. \\
congesta (Wight) Bedd. & Carissa paucinervia A.DC. \\
C. carandas var. paucinervia & Carissa pilosa Schinz \\
(A.DC.) Bedd. & Carissa pubescens A.DC. \\
Carissa cochinchinensis Pierre & Carissa revolute Scott-Elliot \\
ex Pit. & Carissa richardiana Jaub. and \\
Carissa comorensis (Pichon) & Spach \\
Markgr. & Carissa scabra R.Br. \\
Carissa congesta Wight & Carissa sechellensis Baker \\
Carissa coriacea Wall. & Carissa suavissima Bedd. ex \\
Carissa cornifolia Jaub. and & Hook.f. \\
Spach & Carissa tomentosa A.Rich. \\
Carissa dalzellii Bedd. & Carissa villosa Roxb. \\
Carissa densiflora Baker & Carissa xylopicron Thouars \\
Carissa diffusa Roxb. & Carissa yunnanensis Tsiang \\
Carissa dulcis Schumach. and & P.T.Li \\
Thonn. & \\
Carissa edulis (Forssk.) Vahl & \\
Carissa hirsute Roth & \\
Carissa horrida Pichon & \\
\hline C. spinarum: Carissa spinarum & \\
& \\
& \\
&
\end{tabular}

C. spinarum: Carissa spinarum

Table 2: Uses of different parts of the plant [8]

\begin{tabular}{|c|c|c|}
\hline Description & Parts & Use \\
\hline \multicolumn{3}{|l|}{ Medicinal uses } \\
\hline Roots & Root extract & $\begin{array}{l}\text { Purgative, wounds in } \\
\text { animals }\end{array}$ \\
\hline All parts & Glycosidal extract & Cardio tonic \\
\hline \multicolumn{3}{|l|}{ Commercial uses } \\
\hline Leaves and fruits & Fresh & Garlands \\
\hline \multirow[t]{2}{*}{ Fruit } & Raw & Pickles \\
\hline & Ripe & $\begin{array}{l}\text { Syrup, jelly, } \\
\text { preserves }\end{array}$ \\
\hline \multirow[t]{2}{*}{ Leaf } & Green leaves & $\begin{array}{l}\text { Fodder for goats, } \\
\text { fodder for sheep }\end{array}$ \\
\hline & Dried leaves & Tanning industry \\
\hline Plant & Whole plant & $\begin{array}{l}\text { Hedge plant, fragrant } \\
\text { flower, cover crop in } \\
\text { dry rocky areas }\end{array}$ \\
\hline Other uses & Fresh flowers & Personal adornment \\
\hline
\end{tabular}

and diazepam were standard drugs in PTZ-induced convulsion, and phenytoin was standard drug in MEST-induced convulsion [36].

\section{Antidiabetic activity}

EI-Fiky et al. 1995 studied the effects of ethanolic extract of leaves of C. spinarum in streptozotocin-induced diabetes in adult male albino rats. $2000 \mathrm{mg} / \mathrm{kg}$ extract was given orally after to giving $40 \mathrm{mg} / \mathrm{kg}$ streptozotocin by ip route. Blood was collected at $0,1,2$, and $3 \mathrm{~h}$ from each rat and evaluated for blood glucose levels. The extract showed significant antidiabetic activity on comparison with the reference drugs, which were metformin and glibenclamide [37].

\section{Anti-inflammatory activity}

Beck and Namdeo 2016 evaluated anti-inflammatory activity in petroleum ether, chloroform, alcoholic, and aqueous extracts of leaves of C. spinarum at a dose of $200 \mathrm{mg} / \mathrm{kg}$, each given by oral route to albino rats. Formalin was used as an inducer for the inflammation, while analgin $(30 \mathrm{mg} / \mathrm{kg})$ acts as a standard drug. The result of the study shows the percentage of inhibition in standard drug (33.87\%), aqueous extract (17.04\%), alcoholic extract (6.93\%), chloroform extract (6.93\%), and petroleum ether extract (4.76\%). Thus, it was concluded that $C$. spinarum leaves have significant $(\mathrm{p}<0.01)$ anti-inflammatory activity at a dose of $200 \mathrm{mg} / \mathrm{kg}$ [38].

Carrageenan-induced paw edema in chicks was used by Woode et al. 2007 , to evaluate the extract of root powder with $70 \%$ ethanol for antiinflammatory activity. The results of this study suggested that extract inhibits acute edema induced by carrageenan in the chick foot [39].

\section{Antioxidant activity}

The results of Sahreen et al. 2010 show considerable antioxidant activities of chloroform and aqueous fractions of $C$. spinarum fruits. The activity of these fractions is attributed to the phenolic and flavonoid contents. Consequently, the results suggested that the extracts can be utilized as an effective and safe antioxidant source, although the antioxidant activities of chloroform and aqueous fractions were lower than that of ascorbic acid and rutin. This research was done extraction by n-hexane, ethyl acetate, chloroform, butanol, methanol, and water [40].

Rao et al. in 2006 isolated carenone and formulated its synthetic derivatives. All compounds show potent antioxidant activity [41].

Woode et al. 2007 evaluated the extract of root powder with $70 \%$ ethanol for antioxidant and anti-inflammatory activity. The antioxidant study was conducted on the basis of total phenolic content, reducing power, 2,2-diphenyl-1-picryl-hydrazyl-hydrate assay, and lipid peroxidation. The extract shows significant antioxidant activity though it is not as potent as standard drugs [39].

\section{Antimicrobial activity}

Ibrahim et al., 2005 and 2010, in their research on aqueous extracts of fruit and leaves of $C$. spinarum $\mathrm{L}$. showed the extracts to be more active on the Gram-positive organisms (Bacillus subtilis and Staphylococcus

Table 3: Phytochemical testing of leaves of $C$. spinarum $\mathrm{L}$.

\begin{tabular}{|c|c|c|c|c|c|}
\hline Sr. No. & Test for & Petroleum ether extract & Chloroform extract & Ethanolic extract & Aqueous extract \\
\hline 1 & Alkaloids & - & - & + & + \\
\hline 2 & Tannins & - & + & + & + \\
\hline 3 & Flavonoids & - & - & + & + \\
\hline 4 & Saponins & - & - & + & - \\
\hline 5 & Glycosides & - & + & + & - \\
\hline 6 & Terpenoids & - & - & + & - \\
\hline 7 & Carbohydrate and sugars & - & - & + & + \\
\hline 9 & Protein and amino acid & - & - & - & - \\
\hline 10 & Steroids & - & - & + & + \\
\hline 11 & Gums and mucilages & - & - & - & + \\
\hline
\end{tabular}


aureus) compared to Gram-negative organisms (Escherichia coli and Pseudomonas aeruginosa). The aqueous extract of leaves shows more significant antimicrobial activity than fruit extract. Both extracts proved their activity at up to the $1 / 10000$ dilution, which is probably occurs due to the secondary metabolites present in the plant which are tannins, saponins, and flavonoids. As the extract seems more active in Gram-negative bacteria than Gram-positive might be due to the structural difference between them $[42,43]$.

Shahada et al., 2014, prepared extract by making and combining powder of various plant parts and extracted with various solvents by cold maceration method. These extracts were subjected to testing against $S$. aureus and $E$. coli. The result of this study also showed that the activity of the extract was found to be more efficacious in Gram-positive bacteria than Gram-negative [14]

Chandra et al. 2011 evaluated various extracts of fruit of C. spinarum L. at different concentrations ( 10 and $50 \mathrm{mg} / \mathrm{ml}$ ) for antimicrobial activity. Ethanolic extract was found to be having highest efficacy, followed by acetone, aqueous, and ethyl acetate extract, respectively. The degree of inhibition was found highest in Streptococcus pyogenes, S. aures and Bacillus cereus [15].

Another antimicrobial study was conducted by Ngulde et al. 2013 on various strains of microorganisms of ethanolic extract of root bark of C. spinarum L. at doses of $25,50,100$, and $200 \mathrm{mg} / \mathrm{ml}$ with tetracycline $(250 \mathrm{mg} / \mathrm{ml})$ as a standard. In this study, the extract failed to provide action against $S$. aureus, B. subtilis, E. coli, and P. aeruginosa but showed significant activity at doses of 100 and $200 \mathrm{mg} / \mathrm{ml}$ on Salmonella typhi, Shigella dysenteriae, and S. pyogenes [44].

\section{Antileishmanial activity}

A study done by Njau et al. 2016 evaluated preliminary antileishmanial screening of $C$. spinarum extracts performed on the promastigote form of Leishmania major showed that their activity against promastigotes is not in relation to their polarity. The less polar petroleum ether, polar total methanol, and successive methanol extracts recorded moderate activity while the water and less polar extracts (dichloromethane and ethyl acetate) recorded weak activity. The activity of these extracts against the amastigote form of L. major was seen to be dose-dependent. Higher concentrations of $C$. spinarum extracts seemed to reduce the infection rate of macrophages. The polar extracts (water, total methanol, successive methanol, and ethyl acetate) were found to be more active than less polar extracts (petroleum ether and dichloromethane). At

Table 4: Phytochemical parameters of leaves of $C$. spinarum $\mathrm{L}$

\begin{tabular}{lll}
\hline Sr. No. & Analytical parameter Leaves & $\mathbf{\%} \mathbf{w} / \mathbf{w}$ \\
1 & Total ash & 14 \\
2 & Acid-insoluble ash & 5.3 \\
3 & Water-insoluble ash & 6.6 \\
4 & Sulfated ash & 10.3 \\
5 & Alcohol soluble extractive & 4.56 \\
6 & Water-soluble extractive value & 15.62 \\
7 & Chloroform soluble extractive value & 4.3 \\
8 & Loss on drying & 3.62 \\
\hline
\end{tabular}

C. spinarum: Carissa spinarum their highest concentrations $(200 \mu \mathrm{g} / \mathrm{ml})$ all extracts, except petroleum ether, had IR values not significantly different to the standard reference drug pentostam at concentration $50 \mu \mathrm{g} / \mathrm{ml}(\mathrm{p}>0.05)$ [16].

\section{Antinociceptive activity}

Maina et al. 2015 designed a study to bioscreen the dichloromethane: Methanolic extract of the leaf and root bark of C. spinarum for antinociceptive potential. The method utilizes formalin induces pain for evaluation of antinociceptive screening. $30 \mathrm{~min}$ after dosing with standard and reference drugs, all the animals were injected intraperitoneally with $0.1 \mathrm{ml}$ of $2.50 \%$ formalin in the subplantar region of the left hind paw to induce nociceptive behavior of lifting, licking, and biting. The time that the rats spent lifting, licking, or biting the injected paw was, hence, recorded. The responses were divided into two phases, early phase (0-5 min) and late phase (15-30 min). The dichloromethane: Methanolic leaf and root bark extracts of $C$. spinarum, produced non-dose dependent analgesic activity. The highest analgesic effect determined by percent licking inhibition of leaf extracts was by $47.19 \%$ and $84.93 \%$ in the early and late phases, respectively, while by root bark extracts were by $41.89 \%$ and $90.62 \%$ in the early and late phases, respectively [45].

Mworia et al. 2015 conducted a study of acetone extract of $C$. spinarum in Swiss albino mice by formalin-induced pain (paw licking) and acetic acid-induced writing. In this study, the significant antinociceptive effect is observed by reducing formalin paw- licking time in both phases and acetic acid-induced writhing, with more potent activity in the second phase. This suggests both central and peripheral antinociceptive effects [46].

\section{Antioxidant activity}

Hegde and Joshi 2010 evaluated ethanolic extracts of $C$. spinarum roots for in chloroform $\left(\mathrm{CCl}_{4}\right)$-induced as well as paracetamol (PCM)-induced hepatotoxicity. The livers were processed after sacrificing animals and tested for antioxidant activity for reduced glutathione (GSH) estimation, superoxide dismutase (SOD), catalase (CAT) activity, and lipid peroxidation of malondialdehyde (MDA). The results were found to as decreased levels of GSH and MDA, as well as a significant rise in hepatic SOD and CAT activities. These changes contribute to its overall antioxidant activity [47].

\section{Antiplasmodial activity}

Kebenei et al. 2011 evaluated antiplasmodial activity of nortrachelogenin, a compound which is isolated from the root bark of $C$. spinarum $L$. and found that the compound has potential to be the cheap antimalarial drug, and also proves the ethnopharmacological use of the plant [48]. Ayuko et al. 2009 screens the root bark extract and stem bark extract on CQ-sensitive and CQ-resistant strains of Plasmodium falciparum. The result of this study shows that the plant has mild antimalarial activity [49].

\section{Antiviral activity}

Tolo et al. 2006 demonstrated the antiviral activity of aqueous extract of root bark of $C$. spinarum against herpes simplex virus (HSV) for in vitro and in vivo anti-HSV activity, at different parameters such as plaque inhibition assay, cell cytotoxicity assay, virus yield reduction assay, and against Balb/C mice cutaneously infected with HSV. In plaque inhibition assay, the result shows that the resistant strains of the virus were more

Table 5: Phytochemical testing of roots and root bark of $C$. spinarum $\mathrm{L}$.

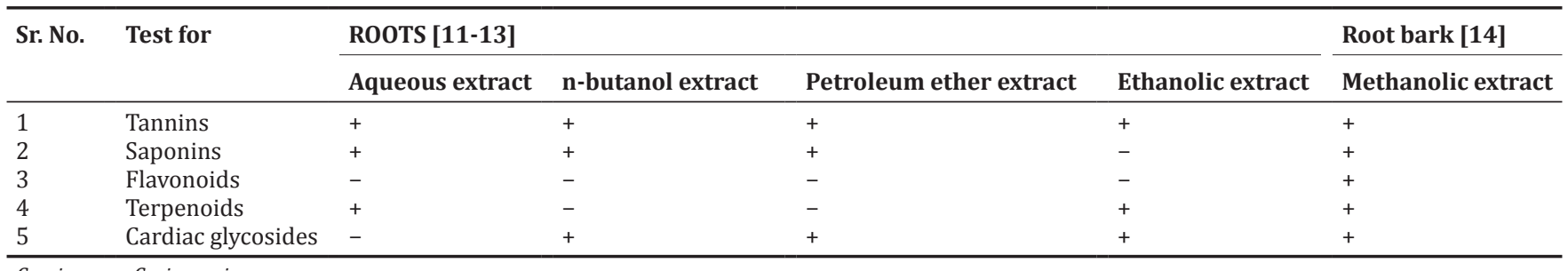

C. spinarum: Carissa spinarum 
susceptible to the extract than the wild-type strains. In yield reduction, assay $200 \mathrm{~g} / \mathrm{ml}$ dose of the extract significantly reduced the virus yields of APr HSV-1 by $100 \%$, HSV- 2 by $99.5 \%$, HSV- 1 by $97.8 \%$, and TK- HSV1 by $96.3 \%$. In the animal experiments using Balb/C mice cutaneously infected with wild-type strains of HSV- 1 or HSV- 2 at $1 \times 10^{6} \mathrm{PFU} /$ mouse, all the infected untreated mice ultimately died, whereas animals treated orally with the extract provided some protection [50].

\section{Cytotoxicity studies}

In vitro cytotoxicity studies on C. spinarum extracts by sulforhodamine-B assay method were evaluated by Doshi and Une 2015. C. spinarum extract showed equivalent activity comparable to the standard compound ADR for human breast cancer cell line MCF7, and also showed mild progressive activity on other two selected cell lines, i.e. human colon cancer cell line HCT15 and human leukemia cell line MOLT4 [51].

\section{Diuretic activity}

Nedi et al. 2004 evaluated the diuretic effect of the root bark and root wood of the plant in albino Wistar rats with $80 \%$ methanol. The extract used in this study was root bark maceration extract, root bark Soxhlet extract, root wood maceration extract, and root wood Soxhlet extract. For the study, all extracts were used at concentration of 50, 125, 250, 500 , and $1000 \mathrm{mg} / \mathrm{kg}$, while hydrochlorothiazide $10 \mathrm{mg} / \mathrm{kg}$ acts as a standard drug. The root bark maceration extract failed to show anti significant diuretic activity, but root bark Soxhlet extract showed the significant diuretic activity. Similarly, the root wood maceration extract showed significant activity even at a dose of $50 \mathrm{mg} / \mathrm{kg}$ on electrolytes. The Soxhlet extract of root wood extract showed diuretic activity till $500 \mathrm{mg} / \mathrm{kg}$, but then at more than $500 \mathrm{mg} / \mathrm{kg}$ test drug failed to produce the diuretic activity. As shown in this study, the extract did not produce a dose-dependent increase in activity, thus giving only mediate diuretic effect [52].

Similar study was conducted by Kebamo et al. 2015. The study was conducted on different solvent fractions of methanol extract of C. spinarum root bark. The study showed that the aqueous fraction of the methanol Soxhlet extract of the root bark of the plant has a significant diuretic activity while the petroleum ether and n-butanol fractions of the extract did not show significant diuresis at the tested doses in rats [11].

\section{Erythropoietic effect}

Koffuor et al. 2012 used the ethanolic root extract of C. spinarum against phenylhydrazine-induced anemia in Sprague Dawley rats at doses of 100,300 , and $1000 \mathrm{mg} / \mathrm{kg}$, while $0.23 \mathrm{ml} / \mathrm{kg}$ bioferon acts as

Table 6: Phytochemical testing of fruit of $C$. spinarum $\mathrm{L}$.

\begin{tabular}{|c|c|c|c|c|}
\hline \multirow[t]{2}{*}{ Sr. No. } & \multirow[t]{2}{*}{ Test for } & \multicolumn{2}{|c|}{ Unripe fruit } & \multirow{2}{*}{$\begin{array}{l}\text { Ripe } \\
\text { fruit }\end{array}$} \\
\hline & & $\begin{array}{l}\text { Petroleum } \\
\text { ether } \\
\text { extract }\end{array}$ & $\begin{array}{l}\text { Methanol } \\
\text { extract }\end{array}$ & \\
\hline 1 & Carbohydrates & + & + & + \\
\hline 2 & Alkaloids & - & + & + \\
\hline 3 & Flavonoid & - & + & + \\
\hline 4 & Tannins and phenolic & - & + & + \\
\hline 5 & Steroids & + & + & + \\
\hline 6 & Terpenoids & - & + & + \\
\hline
\end{tabular}

a reference drug. C. spinarum at doses of 300 and $100 \mathrm{mg} / \mathrm{kg}$ was able to reverse very significantly anemia caused by phenylhydrazine after 45 days of treatment without anisocytosis, thus concluding that the extract has erythropoietic activity with normocytosis [53].

\section{Hepatoprotective activity}

Hegde and Joshi 2010 evaluated ethanolic extracts of $C$. spinarum roots in chloroform $\left(\mathrm{CCl}_{4}\right)$-induced as well as PCM-induced hepatotoxicity. The significant elevation in the levels of serum marker enzymes in control group such as SGOT, SGPT, and SALP content of $\mathrm{CCl}_{4} / \mathrm{PCM}$ shows degree of hepatotoxicity. Animals pre-treated with extract $(100,200$, and $400 \mathrm{mg} / \mathrm{kg}$ ) as well as a standard drug (silymarin) demonstrated significant hepatoprotection by decreasing serum marker enzymes in a dose-dependent manner [47].

Similar studies were conducted by Sahreen et al. 2011, but instead of roots, leaves were selected for screening of potential hepatoprotective activity. Phytochemical analysis of methanolic extract confirmed the presence of alkaloids, anthraquinones, cardiac glycosides, coumarins, flavonoids, saponins, phlobatannins, tannins, and terpenoids, which all are closely related to compounds useful in protection of liver in various mechanisms. $\mathrm{CCl}_{4}$ decreases the activities of hepatic antioxidant enzymes increases the activity of serum marker enzymes, and also significantly increases the hepatic thiobarbituric acid reactive substances (TBARS) and $\mathrm{H}_{2} \mathrm{O}_{2}$ level whereas significantly decreased the GSH and protein content. The result of animals pre-treated with $200 \mathrm{mg} / \mathrm{kg}$ of methanolic extract of Carissa leaves showed reduction in serum marker enzyme activity, increased activity of hepatic antioxidant enzymes and also prevents alteration in TBARS, $\mathrm{H}_{2} \mathrm{O}_{2}$, GSH, and protein content [54].

\section{Wound healing}

Sanwal and Chaudhary, 2011, prepared ointment of the methanolic extract of $C$. spinarum root, which exhibited significant pro-healing activity when topically applied on mice by affecting various stages of healing process, significant amelioration potential by root extract evident by the rate of wound contraction and epithelization, suggesting that the plant has significant wound healing activity [55].

\section{CONCLUSION}

The evergreen shrub of $C$. spinarum has enormous medicinal and cultural value. The plant has a variety of use in day to day life, as well as pharmacological activities. These activities are present due to the presence of a variety of phytochemicals present in the plant. All plant parts have medicinal as well as nutritional value and used for the same traditionally throughout the world especially in African countries. Ethnopharmacological studies of the plant strengthen the concept for utilizing $C$. spinarum plant as a source to facilitate safe and effective herbal treatments for biological problems.

C. spinarum, similar to C. carandas has various medicinal properties [56]. All the plant parts have significant therapeutic activities. Carissa species have shown the presence of phytoconstituents such as alkaloids, flavonoids, glycosides, reducing sugar, steroids, terpenoids, tannins, and saponins, which mostly attributed for the pharmacological activity of the plant [57].

This review is prepared with the aim to provide a reference source for biology, phytochemistry, ethnopharmacology, and research done on the C. spinarum for aid in research of future researchers. The traditional and

Table 7: Phytochemical testing of stem and stem bark of $C$. spinarum $\mathrm{L}$.

\begin{tabular}{|c|c|c|c|c|c|c|c|}
\hline Sr. No. & Test For & Aqueous & Methanolic & Petroleum Ether & Dichloromethane & Ethyl Acetate & Successive methanol \\
\hline 1 & Alkaloids & + & - & + & + & + & - \\
\hline 2 & Terpenoids & + & + & + & + & + & + \\
\hline 3 & Phenols & + & + & + & + & - & + \\
\hline 4 & Anthraquinones & + & + & + & + & + & + \\
\hline 5 & Saponins & + & - & - & + & - & - \\
\hline
\end{tabular}

C. spinarum: Carissa spinarum 
ethnomedicinal literatures showed that the plant is very effective and safe for medicinal uses. Using the reverse pharmacological approaches in natural drug discovery a potent and safe drug can be investigated from the plant for various chronic diseases.

\section{ACKNOWLEDGMENT}

We are grateful to our Principal Dr. (Mrs.) Sudha Rathod, Dr. (Mrs.) Vanita G. Kanase and Dr. Sayyed Mateeen for their guidance and support as well as to Pharmacology Department, Oriental College of Pharmacy, Navi Mumbai.

\section{AUTHOR'S CONTRIBUTION}

We declare that this work was done by the authors named in this article and all liabilities pertaining to claims relating to the content of this article will be borne by the authors. Mr. Diptesh T. Patil collected the data and analyzed the data and prepared the manuscript. Mr. Imtiyaz Ansariproof-read the whole manuscript, and suggested the necessary changes, and helps in designing manuscript.

\section{CONFLICTS OF INTEREST}

The authors declare that there are no conflicts of interest regarding the publication of this paper.

\section{REFERENCES}

1. Tropicos.org. Tropicos Name-Carissa spinarum L; 2018. Available from: http://www.tropicos.org/name/1800028. [Last accessed on 2018 Apr 29].

2. Worldagroforestry.org. Carissa edulis; 2018. Available from: Available from: http://www.worldagroforestry.org/treedb2/speciesprofile.php?Spid=443. [Last accessed on 2018 Jan 28].

3. Govaerts, R. Carissa spinarum L., Mant. Pl 2018;2:559. World Checklist of Selected Plant Families. Available from: http://www.wcsp. science.kew.org/synonomy.do?name_id=34226. [Last accessed on 2018 Jan 28].

4. Theplantlist.org. Carissa spinarum L.-The Plant List; 2018. Available from: http://www.theplantlist.org/tpl1.1/record/kew-34226. [Last accessed on 2018 Jan 28].

5. Sites.google.com. Carissa spinarum-efloraofindia; 2018. Available from: https://www.sites.google.com/site/efloraofindia/species/a---1/a/ apocynaceae/carissa/carissa-congesta. [Last accessed on 2018 Jan 28].

6. Uniprot.org. Carissa spinarum; 2018. Available from: http://www. uniprot.org/taxonomy/429256. [Last accessed on 2018 May 01]

7. Kirtikar K, Basu B. Indian Medicinal Plants. Vol. II. Allahabad: Lalit Mohan Basu; 1980. p. 1548-9.

8. Fatima A, Singh P, Agarwal P, Irchhaiya R, Alok S, Verma A. Treatment of various diseases by Carissa spinarum L.: A promising shrub. Int $\mathrm{J}$ Pharm Sci Res 2013;4:2489-95.

9. Parmar C, Kaushal M. Wild Fruits of the Sub-Himalayan Region. New Delhi: Kalyani; 1982. p. 15-8

10. Beck N, Namdeo K. Preliminary phytochemical and pharmacognostical evaluation of Carissa spinarum leaves. Asian J Pharm Technol 2013;3:30-3

11. Kebamo S. Evaluation of diuretic activity of different solvent fractions of methanol extract of Carissa edulis root bark in rats. Med Chem 2015;5:472-8

12. Onotu C, Musa U, Fajinmi A, Mazadu M, Shaida S. Physiochemical evaluation of ethanolic root extract of Carissa Spinarum (Wild Karanda) on Trypanosoma brucei Brucei (Federe Strain) infected mice. Int J Pharm Sci Invent 2013;2:18-26.

13. Hegde K, Joshi A. Preliminary phytochemical screening and antipyretic activity of Carissa Spinarum root extract. Pharm Lett 2010;2:255-60.

14. Shahada F, Rubaka C, Ndakidemi P, Malebo H. Analysis of phytochemical and antibacterial activity of Carissa spinarum Linn crude extracts. Eur J Med Plants 2014;4:937-45.

15. Chandra S, Saklani S, Kandri A. Nutritional evaluation, antimicrobial activity and phytochemical screening of wild edible fruit (Carissa opaca). Int Res J Pharm 2011;2:217-21.

16. Njau V, Maina E, Anjili C, Ingonga J, Koech J, Kariuki H, et al. In vitro antileishmanial activity and phytochemical analysis of Carissa edulis against Leishmania major. Afr J Pharmacol Ther 2016;5:253-62.

17. Dennis T, Sharma P, Yelne M. Database on medicinal plants used in
Ayurveda. $3^{\text {rd }}$ ed. New Delhi: Central Council for Research in Ayurveda \& Siddha; 2005. p. 369-77.

18. Al-Youssef H, Hassan W. Chemical constituents of Carissa edulis Vahl. Arab J Chem 2017;10:109-13.

19. Bentley M, Brackett S, Chapya A. 2-Hydroxyacetophenone: Principal root volatile of the east African medicinal plant, Carissa edulis. J Natl Prod 1984;47:1056-7.

20. Achenbach H, Waibel R, Addae-Mensah I. Sesquiterpenes from carissa edulis. Phytochemistry 1985;24:2325-8.

21. Achenbach H, Waibel R, Addae-Mensah I. Lignans and other constituents from Carissa edulis. Phytochemistry 1983;22:749-53.

22. Komakech R, Omujal F. Carissa Spinarum: The Magic Herb-News and Views from Emerging Countries SouthWorld; 2016. Available from: http:// www.southworld.net/carissa-spinarum-the-magic-herb/. [Last accessed on 2018 Jan 28].

23. Bussmann R, Gilbreath G, Solio J, Lutura M, Lutuluo R, Kunguru K, et al. Plant use of the maasai of sekenani Valley, Maasai Mara, Kenya. J Ethnobiol Ethnomed 2006;2:22.

24. Giday M, Asfaw Z, Elmqvist T, Woldu Z. An ethnobotanical study of medicinal plants used by the Zay people in Ethiopia. J Ethnopharmacol 2003;85:43-52.

25. Wambugu SN, Mathiu PM, Gakuya DW, Kanui TI, Kabasa JD, Kiama SG, et al. Medicinal plants used in the management of chronic joint pains in Machakos and Makueni counties, Kenya. J Ethnopharmacol 2011;137:945-55.

26. Addis G, Abebe D, Urga K. A survey of traditional medicinal plants in Shirka District, Arsi Zone, Ethiopia. Ethiop Pharm J 2018;19:30-47.

27. Burkill H, Dalziel J, Hutchinson J. The Useful Plants of West Tropical Africa. Kew: Royal Botanic Gardens; 1985.

28. Zafar M, Abbasi A, Khan M, Ahmad M, Khan H, Muhammad N, et al. Medicinal plants used for the treatment of jaundice and hepatitis based on socio-economic documentation. Afr J Biotechnol 2009;8:1643-50.

29. Wutthamawech W. Encyclopaedia of Medicinal Plants. Bangkok: Odeonstore Publishing; 1997. p. 473.

30. Gradé J, Tabuti J, Van Damme P. Ethnoveterinary knowledge in pastoral Karamoja, Uganda. J Ethnopharmacol 2009;122:273-93.

31. Kokwaro J. Medicinal plants of East Africa. $2^{\text {nd }}$ ed. Nairobi: East African Literature Bureau; 1976. p. 26.

32. Pakrashi S, Datta S, Ghosh-Dastidar P. Indian medicinal plantsXVII.3 phytochemical examination of Carissa SPP. Phytochemistry 1968;7:495-6

33. Chopra R, Nayar S, Chopra I. Glossary of Indian Medicinal Plants. New Delhi: Council of Scientific and Industrial Research; 1956. p. 52.

34. Harwansh R, Garabadu D, Rahman M, Garabadu P. In vitro anthelmintic activity of different extracts of root of Carissa spinarum. Int J Pharm Sci Res 2010;1:84-8.

35. Hegde K, Issac C, Joshi A. Antiarthritic activity of Carissa spinarum root extract in freund's adjuvant induced polyarthritis in rats. Pharmacologyonline 2010;2:713-8.

36. Ya'u J, Yaro A, Abubakar M, Anuka J, Hussaini I. Anticonvulsant activity of Carissa edulis (Vahl) (Apocynaceae) root bark extract. J Ethnopharmacol 2008;120:255-8.

37. El-Fiky F, Abou-Karam M, Afify E. Effect of Luffa aegyptiaca (seeds) and Carissa edulis (leaves) extracts on blood glucose level of normal and streptozotocin diabetic rats. J Ethnopharmacol 1996;50:43-7.

38. Beck N, Namdeo K. Evaluation of in-vivo anti-inflammatory activity of leaves Extract of Carissa spinarum on formalin induced paw edema in albino rats. UK J Pharm Biosci 2016;4:36-40.

39. Woode E, Ansah C, Ainooson G, Abotsi W, Mensah A, Duweijua M. Anti-inflammatory and antioxidant properties of the root extract of Carissa edulis (forsk.) Vahl (Apocynaceae). J Sci Technol (Ghana) 2008;27:5-15

40. Sahreen S, Khan M, Khan R. Evaluation of antioxidant activities of various solvent extracts of Carissa opaca fruits. Food Chem 2010;122:1205-11

41. Rao RJ, Kumar US, Reddy SV, Tiwari A, Rao JM. Antioxidants and a new germacrane sesquiterpene from Carissa spinarum. Natl Prod Res 2005;19:763-9.

42. Ibrahim H, Bolaji R, Abdurrahman E, Shok M, Ilyas N, Habib A. Preliminary phytochemical and antimicrobial studies of the leaves of Carissa edulis VAHL. Chem Class J 2005;2:15-8.

43. Ibrahim H, Oyi R, Ehinmidu J, Musa K, Bright N. Antimicrobial activity of the water extracts of the leaves and fruits of Carissa edulis Vahl (Apocynaceae). J Med Plants Res 2010;4:1028-32.

44. Ngulde S, Sandabe U, Tijjani M, Barkindo A, Hussaini I. Phytochemical constituents, antimicrobial screening and acute toxicity studies of the ethanol extract of Carissa edulis Vahl. root bark in rats and mice. Am J 
Res Commun 2013;1:99-110.

45. Maina GS, Kelvin JK, Maina MB, Muriithi NJ, Kiambi MJ, Kelvin JK. Antinociceptive properties of dichloromethane: Methanolic leaf and root bark extracts of Carissa edulis in rats. J Phytopharmacol 2015;4:106-12.

46. Mworia JK, Gitahi SM, Juma KK, Njagi JM, Mwangi BM, Aliyu U, et al. Antinociceptive activities of acetone leaves extracts of Carissa Spinarum in mice. Med Aromat Plants 2015;s1:1-4.

47. Hegde K, Joshi AB. Hepatoprotective and antioxidant effect of Carissa spinarum root extract against $\mathrm{CCl} 4$ and paracetamol-induced hepatic damage in rats. Bangladesh J Pharmacol 2010;5:73-6.

48. Kebenei J, Ndalut P, Sabah A. Anti-plasmodial activity of Nortrachelogenin from the root bark of Carissa edulis (vahl). Int J Appl Res Natl Prod 2011;4:1-5.

49. Ayuko T, Njau R, Cornelius W, Leah N, Ndiege I. In vitro antiplasmodial activity and toxicity assessment of plant extracts used in traditional malaria therapy in the Lake Victoria Region. Mem Inst Oswaldo Cruz 2009;104:689-94.

50. Tolo FM, Rukunga GM, Muli FW, Njagi EN, Njue W, Kumon K, et al. Anti-viral activity of the extracts of a Kenyan medicinal plant Carissa edulis against herpes simplex virus. J Ethnopharmacol 2006;104:92-9.
51. Doshi G, Une H. In vitro cytotoxicity studies on Carissa congesta, Polyalthia longifolia, and Benincasa hispida extracts by Sulforhodamine B assay method. Int J Green Pharm 2015;9:157.

52. Nedi T, Mekonnen N, Urga K. Diuretic effect of the crude extracts of Carissa edulis in rats. J Ethnopharmacol 2004;95:57-61.

53. Koffuor GA, Sam GH, Dadzeasah PE, Owiafe EO, Asante-Gyapong A. Erythropoietic effect of the ethanolic root bark extract of Carissa edulis in Phenylhydrazine-induced anemic Sprague-Dawley rats. Res J Pharmacol 2012;6:20-4.

54. Sahreen S, Khan MR, Khan RA. Hepatoprotective effects of methanol extract of Carissa opaca leaves on CCl4-induced damage in rat. BMC Complementary Altern Med 2011;11:8

55. Sanwal R, Chaudhary A. Wound healing and antimicrobial potential of Carissa spinarum Linn. in albino mice. J Ethnopharmacol 2011;135:792-6.

56. Alam F, Shahriar M, Bhuiyan MA. In-vivo pharmacological investigations of bark extracts of Carissa carandas. Int J Pharm Pharm Sci 2014;6:180-5.

57. Mishra CK, Shrivastava B, Sasmal D. Pharmacognostical standarization and phytochemical identification of fruit and root of Carissa carandas Linn. Int J Pharm Pharm Sci 2013;5 Suppl 3:347-50. 